\title{
At Home with Doors: Practising architectural elements in Yes, These Eyes are the Windows and Between 13 and 15 Steps
}

Journal: Contemporary Theatre Review

Author: $\quad$ Dr Stuart Andrews

School of Arts

University of Surrey

Guildford

GU2 7XH

01483689639

s.andrews@surrey.ac.uk

Word count: 8800 (excluding abstract/keywords)

Biographical note: Stuart Andrews is Senior Lecturer in Theatre and Performance at the University of Surrey (UK). He researches art installations and performances that engage with place and has published in Contemporary Theatre Review and, with Jocelyn Spence and David Frohlich, in the Journal of Media Practice and Digital Creativity. He is currently developing two monographs, one on performing home and one with Matthew Wagner, on the door.

Funding: This work was supported by the British Academy/Leverhulme Trust under Grant Reference SG132602

Disclosure statement: I have no 'financial interest or benefit arising from the direct applications' of this research. I have known Lee Miller and Bob Whalley for some years, which I acknowledge in the work.

Image 1 caption: Spectators at 87 Hackford Road, London, June 2014. Photo @ Stuart Andrews.

Image 2 caption: Miller and Whalley reflecting on the politics of the back door, January 2015. Still image (c) taken from footage by Hannah Megan Lane.

Image 3 caption: Miller explains his feeling of invisibility, as he steps from the street into the passageway, January 2015. Still image $\odot$ taken from footage by Hannah Megan Lane.

Image 4 caption: Whalley opens the far passageway door, January 2015. Still image $\odot$ taken from footage by Hannah Megan Lane. 


\title{
At Home with Doors: Practising architectural elements in Yes, These Eyes are the Windows and Between 13 and 15 Steps
}

\begin{abstract}
This article investigates artistic responses to doors in Yes, These Eyes are the Windows (2014), an installation, and Between 13 and 15 Steps (2015), a practical workshop 'laboratory', which both took place in houses. It argues that doors provide critical points of focus for the practice and study of artistic engagement with place. In so doing, it responds to recent interest by architects and theorists in doors as architectural 'elements', notably Von Meiss, who defines doors as 'site', 'object' and 'threshold' (Koolhaas 2014, Von Meiss 2013). The article considers how artists reveal and reflect on the significance of practising doors as a means of opening up understandings of place.
\end{abstract}

The article proposes that, by addressing ways in which artists attend to elements of architecture, in installation and performance, we will better understand the significance of such elements, separately and in combination, on our sense and practices of place. It addresses performances of external and internal doors in Yes, These Eyes are the Windows and Between 13 and 15 Steps. In both works, artists articulated, commented upon, reimagined and reshaped the ways in which specific doors determine relationships between people and place in a house, and between life in a house and in its local context. The article invites further exploration of doors in installation and performance, as part of a broader investigation of the significance of practising architectural elements in artistic engagements with place.

Keywords: Home, house, installation, place, site-specific performance. 


\section{At Home with Doors: Practising architectural elements in Yes, These Eyes are the Windows and Between 13 and 15 Steps}

I distinctly remember arriving home from my first term at university. Having been cooped-up in a 'study bedroom' as autumn became winter, I remember being astonished by the experience of returning home for Christmas, of family opening the front door and light, warmth and welcome spilling out into the night. The moment was a critical stage in that formative first journey home, in which I took in the world inside the home from outside. In the last couple of years, working with a colleague, Matthew Wagner, I have become fascinated by the ways in which artists practise doors, primarily doors in houses and homes. ${ }^{1}$ In this article, I consider two projects in which doors were critical elements, to begin to question the significance of doors in installation and performance.

To varying degrees, artists and curators have focused on doors in their engagements with place, whether attending to existing doors, or introducing doors into a place. In Between the Door and the Street (2013), Suzanne Lacy invited women to hold conversations on the 'stoop', the steps up to the doors of residential buildings, on Park Place, Brooklyn. By reworking established practices of conversation on the stoop, Lacy enabled participants to hold conversations that crossed between 'private' and 'public'

\footnotetext{
${ }^{1}$ I would like to express my thanks to Matthew Wagner for our shared and continuing investigation of the door, to Lee Miller and Joanne 'Bob' Whalley for welcoming our project into their home, to the editor and the two anonymous reviewers for their considered and valuable advice on an earlier draft of this article, and to the British Academy and the Leverhulme Trust for supporting this research.
} 
realms of home and street, which spectators were invited to observe. ${ }^{2}$ In Border Door (1998), Richard A. Lou installed a door on the Mexico/US border. Where Lacy's work enabled acts of engagement between places, Lou revealed the limited signs of distinction between places either side of the border. Border Door appeared incongruous in the landscape, it questioned the purpose and logic of the border, and reimagined modes of crossing. As Lou observes, the door enabled migrants to cross the border "“with dignity" rather than humiliation. ${ }^{3}$

Despite artistic interest in doors, there has been relatively little scholarly work on doors in arts practice, particularly in terms of place. This may be because doors, and other architectural forms, are so familiar that they escape attention or so much a part of a place that it seems inappropriate to separate them out for analysis. Yet, as an established architectural element, and in the context of recent interest by architects and architecture theorists in 'elements', it seems important to consider the ways in which artists practise doors in installation and performance, and how such work may enrich our understanding of performances of place and point to the possibilities of artistic practise of architectural elements.

\footnotetext{
${ }^{2}$ See Jane Jacobs, writing on the stoop, in The Death and Life of Great American Cities (New York: The Modern Library, 1993).

${ }^{3}$ Richard Lou, cited by Guisela Latorre, 'Border Consciousness and Artivist Aesthetics: Richard Lou's Performance and Multimedia Artwork', American Studies Journal, 57 (2012) online <http://www.asjournal.org/57-2012/richard-lous-performance-andmultimedia-artwork/> [accessed 17 September 2015].
} 
In this article, I address artists' treatment of specific doors in two projects. In Yes, These Eyes are the Windows (2014), Saskia Olde Wolbers created an installation at 87 Hackford Road, London, where Vincent van Gogh had once rented a room (1873-1874). Olde Wolbers is, primarily, a video artist, who creates films of small underwater sets. Here, she constructed an installation in a full-size house, which was temporarily uninhabited and in a poor state of repair. The work was developed with Artangel, an arts commissioning agency in London, which has supported several projects in houses. ${ }^{4}$ Olde Wolbers introduced objects into rooms and speakers that played an audio work, created for the installation. ${ }^{5}$ Many of the internal doors were open and visitors spent half an hour in the house, after which time the doorbell rang to signal that they should leave.

Yes, These Eyes are the Windows focused primarily on Arthur and Shirley Brown's sixty-year residence at No. 87, during which time they modernised the house throughout, only to find, in 1971, that Van Gogh had once rented a room upstairs. The installation reflected on this discovery and the ways this affected their life in the house. The discussion that follows addresses the form and position of specific doors and the ways each one marked relations between places, experiences of place and acts of crossing between places. I situate this discussion within the context of the house having fallen into disrepair. The house had been built close to the Effra, one of London's now underground rivers, which had long threatened the structure. The Browns used their knowledge of Van

\footnotetext{
${ }^{4}$ See also Rachel Whiteread's House (1993) and Gregor Schneider's Die Familie Schneider (2004).

${ }^{5}$ Olde Wolbers worked on the audio installation with Lu Kemp (director), Elena Peña (sound designer), Daniel Pemberton (composer), and Tom Brooke (performer).
} 
Gogh's tenancy to try and protect the house from proposed demolition. While, ultimately, the house was 'saved', the discovery led to considerable public interest in the house, often expressed by way of strangers knocking at the front door.

The second project was part of a collaborative research project (2014-2015), in which Matthew Wagner and I began to investigate the door in theatre and performance. We held a symposium on the door, its form and specific performance phenomena, and we commissioned artists to explore selected phenomena in two practical 'laboratories', which each comprised a series of workshops. I reflect, here, on the second laboratory, in which we commissioned Lee Miller and Joanne 'Bob' Whalley to explore doors in their home in Totnes, Devon. Miller and Whalley collaborate on projects that enquire into everyday practices, and the laboratory grew from such investigations. Tasks included preparing an evening meal, being taken on a guided tour of doors, and surveying entrance doors to local houses. Workshops were interspersed with opportunities for emerging discussion, to reflect on and generate findings. Access to Miller and Whalley's house is via a passageway, with doors at either end, which takes approximately 13 and 15 steps to walk, and which gave rise to a working title, Between 13 and 15 Steps.

I am interested in knowing how these projects develop our understanding of the door in artistic engagements with place. In this work, I attend to the ways in which artists practise doors when responding to place, and enable spectators or participants to engage with doors in practical, embodied ways. This study develops my own broader investigations into the ways artists practise places of crossing and engage in 
performances of home. ${ }^{6}$ The two projects take quite different approaches to the door. Olde Wolbers used the front door to begin and end the installation and, variously, left interior doors open, closed and ajar. The second project was developmental and specifically premised on understanding the door through artistic engagement with a home. Doors were a distinctive part of the first piece and the core focus of the second.

For each project, I discuss the material form of doors, their context and the acts and implications of practising specific doors. My intention is to demonstrate the significance of artistic treatment of doors as an intriguing phenomenon in its own right and evidence of the broader value of engaging critically and creatively with architectural elements, particularly the door. In discussing each project, I find that doors necessarily position people and places in a practical relationship, of varying sorts. By addressing acts at the intersection of places, we can discern particular ways in which artists understand, articulate and reimagine relations between places, the form and richness of conversation between places, the effect of one place on another and, thereby, our relation with both the place we are in and places to which we are connected.

\section{The Door}

\footnotetext{
${ }^{6}$ See Stuart Andrews, 'Surge, Sway and Yaw: Mooring Performances in The Boat Project and A Room for London', Contemporary Theatre Review, 25.4 (2015), pp. 502517.
} 
While the door has received relatively limited attention in the arts, it has been discussed in allied fields, notably architecture. ${ }^{7}$ In 2014 , as Director of the $14^{\text {th }}$ International Architecture Exhibition, Rem Koolhaas focused on 'fundamentals', and curated the Elements of Architecture exhibition, with accompanying publication, Elements, in which the door comprised one 'element'. A year earlier, Pierre von Meiss published a substantial revision of Elements of Architecture: From Form to Place (1990). By addressing artistic practice of architectural elements, we may impact on how such elements are understood both in and beyond the arts.

For Von Meiss, 'to build is first of all to create, to define and limit a portion of land distinct from the rest of the world and assign a specific role to it' ${ }^{\mathbf{8}}$ In this context, the door and 'doorway' combine as a 'threshold', that allows us to cross limits, but also both an object and a place. ${ }^{9}$ In our broader study of the door, Wagner and I are keen to understand how Von Meiss's sense of the door, as place, object and threshold, might inform artistic practice and research on place. Writers and architects have long explored the ways in which individuals encounter architectural elements, notably doors, and how these situate people in particular relationships. Peter Kohane and Michael Hill observe that early modern architecture focused on the body, that doors and windows 'could be likened to the sensory apertures of living beings' and that these framed and

\footnotetext{
${ }^{7}$ Writers have also addressed the door as metaphor, notably, David Carr reflects on the museum as an 'inviting door' in, A Place Not A Place: Reflection and Possibility in Museums and Libraries (Oxford: Altamira Press, 2006), p. 26.

${ }^{8}$ Pierre von Meiss, Elements of Architecture: From Form to Place + Tectonics, $2^{\text {nd }}$ ed., (Abingdon: Routledge, 2013), p. 215.

${ }^{9}$ Ibid.
} 
'theatricalised' bodies, situating them in distinct ordering systems. ${ }^{10}$ As they suggest of doors and windows,

Use was not defined as mere functionalism, but in terms of performance; decoration was keyed to status, of the building and its occupant, but also of the door or window within the hierarchic order of the building itself; the symmetry of fenestration contributed to the decorum of the city. ${ }^{11}$

For Kohane and Hill, the emergence of modernist architecture led to a reduction in 'the theatricality of openings'. ${ }^{12}$ While a broad survey, focused on European architecture, their work demonstrates the ways in which doors and windows have been used to perform and sustain systems, structures and identities. Such findings are echoed in studies of specific types of door, notably Laurent Stalder's finding that victims caught in early revolving doors 'deviated from the typical body foreseen for this machine'. ${ }^{13}$ Doors enable certain practices, and, while they may allow for some variation, unexpected or prohibited use can have significant consequences for body and identity.

\footnotetext{
${ }^{10}$ Peter Kohane and Michael Hill base their analysis on architectural writing in English, French and Italian, in 'The Decorum of Doors and Windows, from the Fifteenth to the Eighteenth Century' in Architectural Research Quarterly, 10.02 (2006), pp. 141-156 (p.153).

${ }^{11}$ Ibid.

${ }^{12}$ Ibid. (p.141).

${ }^{13}$ Laurent Stalder, 'Turning Architecture Inside Out: Revolving Doors and Other Threshold Devices', Journal of Design History, 22.1 (2009), pp. 69-77, (p. 74), cited in Siyaves Azeri, 'Evolving Concepts, Revolving Doors', Space and Culture, 18.3 (2015), pp. 220-229, (p.226).
} 
In everyday life, we engage with doors through practice and describe them through a lexicon of terms, which includes those that describe movement. Doors can 'swing' and 'strike' at a 'plate', incorporate parts that 'stop', 'jamb' and lock movement, and 'stick', creak, warp and 'rattle' in their frames. ${ }^{14}$ By practising a door, we become familiar with its touch, weight and idiosyncrasies, with it expanding and contracting, and with leaving it open, ajar or pushed to. We learn its fit in the frame. The ways in which we sense and practise a door resonate with phenomenological approaches to architecture. As Juhani Pallasmaa reflects,

I cannot remember the appearance of the door to my grandfather's farmhouse in my early childhood, but I do remember the resistance of its weight and the patina of its wood surface scarred by decades of use... ${ }^{15}$

Pallasmaa finds his remembered experience outlasts any visual memory. Perhaps this is because the door is one of few architectural elements that moves with our touch. In recalling the sensation and movement of a door, we remember ourselves at a particular point in life, in and between places.

In using doors in everyday life, we make them legible, through situated, embodied, lived practice. As Michel de Certeau observes, we can craft everyday 'ways of

${ }^{14}$ Terms drawn from E. R. Hann, 'Keeping Doors at Their Best' in Popular Mechanics, 92.6 (December 1949), pp. 194-199 (pp.194-198).

${ }^{15}$ Juhani Pallasmaa, The Eyes of the Skin: Architecture and the Senses (Chichester: John Wiley \& Sons, 1996), p. 54. 
using the constraining order' of a place to establish 'a degree of plurality and creativity', which he identifies as 'an art of being in between'. ${ }^{16}$ We may or may not perceive a door as part of a 'constraining order', nor those who practise doors as necessarily 'weak', as in de Certeau's discussion of strategies and tactics, but a door does impose a frame, it can constrain movement and doors are familiar forms in the maintenance of order, notably a prison cell door. ${ }^{17}$ In the arts, it becomes particularly critical to understand how artists engage with a door, whether as an extension to or reimagining of everyday practices, or as evidence of strategies and tactics in play. By attending to the ways artists practise doors, we are able to chart distinct ways in which artists respond to the materiality and limits of place, and so reflect on details including the framing of body and identity in specific contexts and conditions, the touch and movement of a door, actual or implied constraints to use and movement, and the significance of using (or not using) particular doors.

\section{Performing Doors}

As architects and architecture theorists are reflecting on elements, it seems appropriate that, as artists and researchers, we look to the practices by which we understand and engage with these elements in the arts, particularly given established interest in place in performance. While it may seem reductive to look at elements in isolation, it also seems valuable to understand how they might inform artistic engagement with place, whether singly or in combination. On one level, such work investigates

${ }^{16}$ Michel de Certeau, The Practice of Everyday Life (Berkeley: University of California Press, 1988), p. 30, emphasis in original.

${ }^{17}$ Ibid., p.34. 
artists' relationships with elements and, on another, allows us to open up what may prove to be previously hidden layers of detail in artistic engagements with place.

Gay McAuley reflects on the significance of doors in theatre, both those in a theatre venue and doors that separate on- and off-stage worlds. She considers the significance of varying forms of doors, or 'material means providing' access. ${ }^{18}$ She recognises the potential for a contrast between perceptions of doors and the places onto which they open, for instance, the promise of the world beyond a stage door and, at times, the 'bleak' and 'unmarked' reality. ${ }^{19}$ In drawing together this variety, McAuley finds that, in the theatre, 'the nature of the door articulates the relationship between the here and the beyond' ${ }^{20}$ Situating this discussion of doors within her broader study of space in theatre venues, McAuley reveals ways theatre-makers might address architecture as a critical constituent of performance. Her work invites us to look further at the door and, as I consider here, at the ways in which artists practice doors, particularly those in and to a house.

Doors are particularly relevant to emerging work on mobile performance and the ways artists and spectators cross between places. In theorizing mooring performance, in

${ }^{18}$ Gay McAuley, Space in Performance: Making Meaning in the Theatre (Ann Arbor, University of Michigan, 1999), p. 87. For further writing on doors on stage, see Arnold Aronson, 2004, 'Their Exits and Their Entrances: Getting a Handle on Doors', New Theatre Quarterly 20.4 (November 2004), pp. 331-340; Arnold Aronson, Looking into the Abyss: Essays in Scenography (Ann Arbor: University of Michigan Press, 2005); and Tim Fitzpatrick, Playwright, Space and Place in Early Modern Performance: Shakespeare and Company (Farnham: Ashgate, 2011).

${ }^{19}$ McAuley, Space in Performance, p, 67.

${ }^{20}$ Ibid., p. 87. 
response to work by Hannam, Sheller and Urry on moorings, I reflect on the significance of acts and places of mooring at 'the intersection of land and water', and before and after journeys. ${ }^{21}$ There are clear connections between the mooring of a boat at the intersection of land and water, and performance at a door between 'here' and 'beyond'. In both cases, it is important to investigate how artists attend to objects, places, thresholds and acts of crossing, in order to understand what happens when they, or we, as participants, inhabit a crossing, or pass from one place to another. Similarly, both arts practice and analysis can begin to unpick the differences between places that connect at moorings or doors.

Further, work on moorings suggests that artists and researchers can productively chart the ways in which acts, objects and places of crossing, whether at moorings or doors, define places that connect for a time.

Work on moorings and performance points to the impact of an artist's actions on limits between places. In this context, while doors connect, they also separate. Where doors are locked, blocked up, abandoned, unused or disused, the places beyond become, variously, other, separate, excluded, or forgotten. Such separation risks creating a form of 'islandisation' in which 'continuous natural habitats' are 'fragmented into disjunctive pieces', thereby reducing biodiversity. ${ }^{22}$ By closing doors or restricting access, individuals, whether artists or not, may contribute to and may even construct difference where previously none may have existed, with the effect that some excluded places

\footnotetext{
${ }^{21}$ Andrews, 'Surge, Sway and Yaw', p. 505.

${ }^{22}$ Jared M. Diamond, 'The Island Dilemma: Lessons of Modern Biogeographic Studies for the Design of Natural Reserves', Biological Conservation, 7.2 (February 1975), pp. 129-146, (p. 130).
} 
become unsustainable in critical ways. In such cases, a door does not merely separate worlds but leaves them fragmented and diminished. For Jane Jacobs, the connection between house and street is vital to the life of cities, but may be similarly critical to the life of other contexts and communities. ${ }^{23}$ In investigating the ways artists practise doors in houses, I am acutely aware of this broader context in which practices at doors impact on surrounding environments and on those who engage with these environments.

The two projects I discuss here both took place in domestic dwellings, one owned but empty, one owned and inhabited. Kohane and Hill suggest that, '[w]ith regard to doors, there are two sorts of movement, namely the entry into the building and then circulation within it'. ${ }^{24}$ Consequently, I focus on acts at entrance doors, before considering those of circulation at two additional doors in each project. By addressing artistic practice of doors in each work, I set out how these artists treated and practised specific doors, addressed doors as points of intersection between places, and, thereby, conceived of and contributed to relationships between adjoining worlds.

\section{[Insert Image 1]}

\section{Yes, These Eyes are the Windows}

It is almost $8.30 \mathrm{pm}$ on a warm June evening in 2014. In ones and twos, six spectators gather outside 87 Hackford Road, London, a Georgian terraced house that has

\footnotetext{
${ }^{23}$ Jacobs, The Death and Life of Great American Cities (New York: Vintage Books, 1992).

${ }^{24}$ Kohane and Hill, 'The Decorum of Doors and Windows', p. 142.
} 
seen better days (see image one). Paint peels from the walls and the garden has a wild air. The brown front door, scuffed in places, has old, brass fittings: house number, doorknob, letterbox, and two holes from which a door knocker may have been removed. Both of its two original glass panes have been boarded up from inside, and the glass in one is missing. To the other, a reinforced glass pane, a printed sheet of paper has been taped.

The words read,

You are invited.

Ring the doorbell once at your allotted time.

Enter together.

Close the door behind you.

We will begin.

My voice and my light will guide you through the house.

I will guide you up through my floors.

Others will be present. But follow me.

After our conversation is over you are free to wander through my rooms.

When the doorbell goes new visitors will be waiting.

All leave together.

Go on your way. ${ }^{25}$

${ }^{25}$ Olde Wolbers, Yes, These Eyes are the Windows, 87 Hackford Road, London, 19 June 2014. 
Spectators were invited inside, as if by the house itself. For Artangel, 'the house [was] narrating its own story of the search for elusive traces of the famous artist' ${ }^{\prime 26}$ This was one of a number of works in which artists have created installations or performances that reimagine architecture, sometimes involving performers, sometimes not. ${ }^{27}$ It seems particularly critical to reflect on the door in this seam of work that so directly focuses on architecture and in which any human actions often constitute a relatively minor, or obscured part in an event. In this case, the process of reimagining began at the front door.

Front doors have long been understood as critical points of transition. As Céline Rosselin notes, 'the threshold of the front door, being between the private and the public space, is of special importance' ${ }^{28}$ Rosselin identifies considerable anthropological interest in thresholds, notably by Arnold Van Gennep, who discusses thresholds in terms of time and specific stages of life. ${ }^{29}$ While these may seem far removed from the apparent ordinariness of a door, Van Gennep identifies doors, particularly entrance doors, as significant thresholds, which differ according to building type. For Van Gennep,

the door is the boundary between the foreign and domestic worlds in the case of an ordinary dwelling, between the profane and sacred worlds in the

\footnotetext{
${ }^{26}$ Artangel, 'Yes, These Eyes are the Windows - Image 5 of 12' <http://www.artangel.org.uk/projects/2014/yes_these_eyes/slideshow/photograph_by_m arcus_j_leith_4> [accessed 4 October 2015].

${ }^{27}$ See, for instance, Heiner Goebbels Stifters Dinge (2007), also co-commissioned by Artangel, and NVA, Hinterland (Cardross, Argyll and Bute, 2016).

${ }^{28}$ Céline Rosselin 'The Ins and Outs of the Hall: A Parisian Example' in At Home: An Anthropology of Domestic Space, ed. by Irene Cieraad (Syracuse, NY: Syracuse University Press, 2006), Kindle Loc 687.

${ }^{29}$ Arnold van Gennep, The Rites of Passage (London: Routledge, 2004), (p. 188-189).
} 
case of a temple. Therefore, to cross the threshold is to unite oneself with a new world..$^{30}$

We can extend Van Gennep's approach to address specific doors in particular buildings, the conditions and context in which these doors operate as thresholds, and the practices that take place at those doors. However, by opening the front door of No.87, it was difficult to discern features of the 'new world' into which we, as spectators, were crossing. There was no interaction on the doorstep, nor any negotiation of the conditions of entrance. We were crossing without being entirely aware of the consequences. What became apparent was that it was not the crossing itself that was significant. While the door remained open, we were still free to slip away. But, by closing the door, we separated ourselves from one world and committed ourselves to another, in this case, unknown.

Conventionally, Rosselin observes, in everyday life, we might expect a host to open and close a door, demonstrating that we are welcome. But what happens when the host has died, moved away, or when we are, to varying degrees, permitted to let ourselves in? In developing this project, Olde Wolbers invited people who knew about Van Gogh and about the house, to meet her there. As an artist temporarily engaged with the house, Olde Wolbers invited in people who knew more about the house than she did herself. In devising the work and in the timed installations, she demonstrated that it can be productive to draw attention to and revise acts and conditions of welcoming visitors or

${ }^{30}$ Ibid., p. 20. 
entering a house. In the installation, this sensation of revision was particularly acute in those first moments in the darkened hall, in which spectators were situated between doors, neither entirely outside nor inside, left to attend to their position of being held both in and out of places for a time.

For Von Meiss, 'a well-defined hall prevents one from seeing into an apartment's more private spaces', ${ }^{31}$ which he finds speaks to what Roderick Lawrence identifies as a persistent desire for "sequences of privacy" from exterior to interior. ${ }^{32} \mathrm{~A}$ hall is a place to shift one's practices from outside to inside - in Rosselin's terms, 'a protective and neutralizing zone to prevent or ease transition from the public to the private world.' ${ }^{33}$ To understand a hall, Rosselin demonstrates we must address the means by which we are enclosed or, in this case, by which we, as spectators, enclosed ourselves in the private world. The experience revealed ways in which doors and acts, in combination, condition one's entrance into a building. The lack of personal invitation, the written rules and long moments waiting in the hall indicated that we, as outsiders, were permitted but not entirely welcome.

A spectator tried the door to the right, which opened easily. Perhaps it had been released remotely, perhaps it had been unlocked all the time. We walked into the living room and, moments later, a voice began speaking, played from a portable speaker. The

\footnotetext{
${ }^{31}$ Von Meiss, Elements of Architecture, p. 219.

32 Ibid., p. 219, citing Roderick Lawrence, 'The Simulation of Domestic Space: Users and Architects Participating in the Architectural Design Process', Simulation and Games 11.3 (September 1980) pp. 279-300, (n.p.).

${ }^{33}$ Rosselin, 'The Ins and Outs of the Hall', Kindle Loc 704.
} 
narrative spread on speakers through the house, which we followed more or less individually. The voice, which appeared to be that of the house, reflected on the blue plaque on the wall outside the house, for which the Browns had petitioned, in the hope it would preserve the house from demolition. The plaque commemorates Van Gogh's short stay at the house and the voice noted that, as Arthur Brown had feared, it utterly transformed the relationship between house and street at the front door. ${ }^{34}$ The voice continued,

\begin{abstract}
After its unveiling, the crowd on the street has stormed through my front door like they owned the place. Since then, journalists, psychic readers, souvenir-seekers, the odd crank, and you started populating the pavement outside. ${ }^{35}$
\end{abstract}

It was curious to be addressed in this way and the moment contributed to the sense of awkward address established at front and living room doors, that we were suffered, rather than welcome. Akiko Busch reflects that, '[i]f there is any part of the home that does not belong exclusively to the people who live there, it is the front door' ${ }^{\mathbf{3 6}}$ The plaque compounded Busch's observation. Having argued for the plaque, the Browns may have felt obliged to admit the gathering crowds. As the plaque focused public

\footnotetext{
${ }^{34}$ The Blue Plaques scheme, currently administered by English Heritage, commemorates people and events by installing blue plaques on the front of buildings in London. English Heritage, 'Blue Plaques' n.d. <http://www.english-heritage.org.uk/visit/blue-plaques/> [accessed 4 October 2015].

35 Olde Wolbers, Yes, These Eyes are the Windows, emphasis added.

${ }^{36}$ Akiko Busch, The Geography of Home: Writings on Where We Live (New York: Princeton Architectural Press, 1999), p. 37.
} 
attention on the house, it was little wonder that some responded by seeking admittance, with varying senses of entitlement. By situating spectators within this 'crowd', Olde Wolbers revealed long-established practices of attention and reluctant welcome at the door, in which the public intervened in a private place. We stood, awkwardly, as a passerby peered at the house for a time and then walked on. From inside, despite being aware of our own position, the sensation was unsettling, even threatening.

\section{The Bathroom Door}

While most of the doors stood wide open, the bathroom door had been wedged ajar, allowing only a narrow view of a faded blue room. It was unclear if we were allowed or expected to enter to this room, although there was just space to squeeze through the gap. Inside, the decay was clearly apparent. There was rubble in the bath and the ceiling had split, revealing a beam that had twisted out of shape, perhaps through water from the River Effra. From inside, the door appeared half-closed, obscuring the landing and there were no obvious speakers in the room, which separated the room from the remainder of the house.

The partially-open door has long been a compelling form, as Vaughan Hart identifies in Christian and, earlier, pagan iconography, in part because it makes a particular offer. Hart records that, on Roman tombs, a half-open door 'represented hope for the soul's resurrection', yet without the security of 'eternal life' offered by the open 
door. ${ }^{37}$ In the home, a half-open door can offer a quite different sense of promise or release. Gaston Bachelard reflects that,

On May nights, when so many doors are closed, there is one that is just barely ajar. We have only to give it a very slight push! The hinges have been well oiled and our fate becomes visible. ${ }^{38}$

For Bachelard, a single door, even 'just barely ajar' reveals the promise of life beyond the home, a 'fate' that appears pre-destined. A door left ajar is a chink in defences, a precious allowance, giving at the lightest touch. In reflecting on a quite different door left ajar, in the painting, Interior with a Woman Standing (Vilhelm Hammershøi, 1905), Subha Mukherji recalls Bachelard, suggesting that 'the lure of the image lies partly in the infinite possibilities of what Gaston Bachelard might have called objects that may be opened'. ${ }^{39}$ How, though, do such doors open? As Beci Dobbin observes, Leona Toker finds that "“a door that has come ajar" is a critical image in the writing of Vladimir Nabokov. ${ }^{40}$ Where Bachelard sensed fate at a half-open door, Toker finds it envisages “"escape, (mis)adventure or death"', acts we may make, discover and that are done to

${ }^{37}$ Vaughan Hart, 'Sigurd Lewerentz and the "Half-Open Door"' in Architectural History, 39, (1996), pp. 181-196, (p. 189).

${ }^{38}$ Gaston Bachelard, The Poetics of Space (Massachusetts: Beacon Press, 1994), (p. 222223).

${ }^{39}$ Subha Mukherji, 'Introduction', Thinking on Thresholds: The Poetics of Transitive Spaces, ed. by Mukherji (London: Anthem Press, 2011), xvii-xxvii, (p. xvii).

${ }^{40}$ Leona Toker, Nabokov: The Mystery of Literary Structures, (Ithaca: Cornell University Press, 1989), p. 60, cited in Beci Dobbin, “The Queer Part Doors Play” in Nabokov's Laughter in the Dark', Thinking on Thresholds: The Poetics of Transitive Spaces, ed. by Mukerji (London: Anthem Press, 2011), p. 30. 
us. ${ }^{41}$ To differing degrees, Olde Wolbers and these writers ask that, whether in art or everyday life, we attend to the state of a partially-open door, the reasons for its openness, the possibility of altering its position, the promise or portent it implies, and how we might act in response. In attending to such details, we begin to understand the ways in which a partially-open door situates individuals at a point between worlds and, in so doing, reveals the tenuousness of their connections and the ease of separation from particular places.

Perhaps the bathroom door came ajar of its own accord, but it was then caught or pushed against the warp of the wooden floor, its 'infinite possibilities' run aground. The house had been moving for some time, welling up, joists and joints weaving off course. These movements unsettled any possibility of our controlling doors, of closing off one place from another. They pointed to the inevitability of change in an unattended house. As the house opened up, so neatly separated rooms returned to an interconnected world with little place for doors. The door fixed ajar was one of a number of breaches appearing in the house: a broader project of decay in which the house itself was opening and closing by turns. Squeezing between door and jamb, I sought to experience the possibility beyond. In so doing, I became acutely aware of contributing to long-standing practices of testing and breaching both thresholds and limits in the house, by the water that had long destabilised its structure, and by people pressing to see inside.

\section{The Bedroom Door}

${ }^{41}$ Toker, Nabokov, p. 60, cited in Dobbin, 'The Queer Part Doors Play’ p. 30. 
Van Gogh was rumoured to have rented a top floor room in the house. The door stood wide open and, from the landing, the whole room was visible, paper peeling from walls and ceiling. The door evidenced the Browns' renovation, in the form of a thin wooden panel presumably tacked over panelling. Having discovered their famous resident soon after decorating, Laura Allsop suggests that the Browns may have been unsure whether to reverse their handiwork and, ultimately, left the house to decay around them. ${ }^{42}$ The result was a door that revealed more about the Brown's transformations than Van Gogh's life a century earlier. The Browns had, purposefully, limited any sense of threshold here; such panels were intended to smooth the fuss of earlier decorative styles. In that moment, wide-open, the door obscured little and led directly into the room, with light streaming through windows ahead. In their work on aural culture, Barry Blesser and Linda-Ruth Salter discuss the effects that sounds of an open door have on perceptions of place. ${ }^{43}$ Their work suggests the open door reduced any sensation of crossing into the room. Had the door been closed, the landing would have been darker, the sound more constrained, the sense of enclosure greater.

Busch reflects that 'the bedroom is the place where we engage in some of our more formative experiences, the landscape of affecting and profound personal revelations. ${ }^{44}$ While she recognises that perceptions of bedrooms and sleeping

\footnotetext{
${ }^{42}$ Laura Allsop, 2014, 'A House as Art: Van Gogh's London Home', AnOther Magazine $<$ http://www.anothermag.com/art-photography/3591/a-house-as-art-van-goghs-londonhome> [accessed 20 April 2016].

${ }^{43}$ Barry Blesser and Linda-Ruth Salter, Spaces Speak, Are You Listening? Experiencing Aural Culture (Cambridge, Mass: MIT Press, 2007), p. 44.

${ }^{44}$ Busch The Geography of Home, p. 118.
} 
arrangements vary over time, the soundtrack revealed that Van Gogh had particularly affecting feelings for his landlady's daughter, Eugenie Loyer. The recorded voice wondered if Loyer was Van Gogh's first love, if she inspired his decision to begin painting and if her child might have been Van Gogh's. The plain surfaces almost entirely obscured the door that Van Gogh would have known and smoothed away any such signs of experience and revelation. The open door offered no obstructions to limit vision or slow a crossing and no need to learn its particularities. Indeed, it allowed in light, which softened the distinction between room and landing. The Browns and, later, Olde Wolbers' finding or setting of the open door both diminished past formations of place and of this threshold, which would have allowed distinct worlds and experience to form either side.

Olde Wolbers' piece was not explicitly about doors. Yet, investigating the doors in Yes, These Eyes are the Windows begins to reveal that forms and practices of doors are critical to Olde Wolbers' account of 87 Hackford Road. In the brief time before the house was re-modelled, the artwork allowed visitors to reflect on the Browns' treatments of doors, particularly drawing members of the public to the front door, smoothing away signs of the past and, ultimately, in their reluctant acceptance that they were unable to hold back either the river, or the tide of visitors. Olde Wolbers' artwork revealed that the treatment of doors establishes particular offers and expectations of the security of the place we are in and of the possibilities of places beyond. It also revealed that, by attending to the position or state of a door, in art or everyday life, we can better understand a given door, the relation between worlds either side, and the ways in which 
we cross between these worlds. In the remodelling of the house, it remains to be seen whether, how, and to what effect internal and external limits and thresholds will be re-set, how water and 'the crowd', which have so affected practices of the doors at the house, will be treated, and how passers-by will respond as they stop to look in from the street.

\section{Between 13 and 15 Steps}

The second case study took place at the home of Lee Miller and Joanne 'Bob' Whalley in Totnes, Devon. The house is tricky to find. In between two shop fronts on the High Street, a black door leads onto a narrow, permissive passageway. At the end of the passageway is a second door, with a mechanism that takes practise, and which leads into a small courtyard. ${ }^{45}$ Miller and Whalley's house is one of the houses on the courtyard. There are two entrances, ostensibly a 'front' door and 'back' door, although these are only a few feet apart. At night, the passageway is impossibly dark. If I ask Lee Miller, he'll tell me to count thirteen steps from the first door before opening the second. If I ask Bob Whalley, she'll shake her head wryly and tell me it is, in fact, fifteen steps, although, often, she doesn't count at all, but trusts she will know the door in the dark.

Whalley and Miller have lived at this house since 2007, and, for the past few years, I have visited them there once or twice a year. As performance-makers, academics and a married couple, they create dialogic work that reflects, in part, on their life together, although they had never performed publicly in their home. Wagner and I were

\footnotetext{
${ }^{45}$ The passageway runs on through a further door and another street, but I have rarely been taken this way.
} 
interested in knowing how they might attend to the door at home in arts practice and commissioned them to conduct a four-day practical research 'laboratory', comprising workshops on the door, in January 2015. We ran the laboratory as part of our larger project on doors in performance. As co-convenor of that project, I participated in this laboratory. Wagner and I invited a filmmaker, Hannah Lane, to document the work, and a performer, Bella Sabbagh, to participate. Both had been involved in our symposium and first laboratory. Miller, Whalley and I discussed the laboratory on email and in a preparatory discussion beforehand. Miller and Whalley invited me to stay at their house during the project, and Wagner and I rented a house in Totnes for Lane and Sabbagh, so they would also experience being 'guests' of a kind in a house.

Miller and Whalley focused the laboratory on invitation and threshold at the door, and employed their established working practice. They prepared material in advance, refined this a day ahead and left time to respond to emerging activities and findings. They set out to attend to their own acts of living with doors and they invited Lane, Sabbagh and I to participate in and discover and reflect on our own acts within this process. They determined that the work would focus on doors to rooms and doors within rooms. Tasks included a tour of the 27 doors in the house (once cupboard doors are included, it appears that houses can be surprisingly well served by doors); exploring, adding to and cooking food from kitchen cupboards; an installation in the passageway; and a survey of doors in Totnes. Throughout, Miller and Whalley initiated and encouraged conversation, often over tea and home-made cakes around the kitchen table, which had, itself, once been a 
door to an old farm building. The laboratory concluded with a sharing of food and findings for some of Miller and Whalley's close friends.

For Miller and Whalley, this kind of investigation 'spirals out from the domestic', in this case 'looping' in guests. ${ }^{46}$ During the laboratory they reflected that Lane, Sabbagh and I became, in their terms, increasingly 'resident' in the work, house and home. They shared and invited us to practise their tricks of using the old, particular doors and so implicated us in critical practices of their home. Miller and Whalley's spiral approach reflects their established interest in John Law's argument that, '[i]f the world is complex and messy, then at least some of the time we're going to have to give up on simplicities' and 'teach ourselves to think, to practise, to relate, and to know in new ways'. ${ }^{47}$ They planned that the work would emerge from the 'messiness' of their home, from noticing and investigating familiar practices and testing variations. In so doing, Miller and Whalley recognised the project would contribute to their own spiral of attending to and reflecting on the architecture of the house and activities of everyday life. As this is an old house, built around 1585, activities focused particularly on issues affecting doors in old buildings. In reflecting on the work here, I focus on three doors that became particularly significant to our spiralling investigation of doors: the back door, larder door and passageway door to the street.

\footnotetext{
${ }^{46}$ Miller, Whalley, Andrews and Wagner, Between 13 and 15 Steps, Totnes, 12-15 January 2015. 47 John Law, After Method: Mess in Social Science Research (Abingdon: Routledge, 2004), p. 2.
} 


\section{The Back Door}

The house was built as two shops, a butcher's and a baker's, with rooms above. When converted into a house, the separate entrances became front and back doors. They are both blue-grey in colour and both open onto the hall. The windows in the front door are large, the door smartly finished and the interior doormat recessed. The back door is more roughly fashioned, with a small glass pane and a loose mat on an exterior flagstone. A small set of bells hangs from the handle. Miller and Whalley primarily use the back door to the house and had, until recently, blocked the front door with furniture, although Whalley currently uses the front door for acupuncture clients. In one workshop, Miller and Whalley stood outside the house to reflect on the doors and, later, tested the experience of welcoming people at the front door from inside.

\section{[Insert Image 2]}

For Miller and Whalley, back doors offer a mode of encounter with the world that is rooted in class distinction and community. In the UK, back doors have often been associated with local, working class community life. In his 1987-1988 study of a Hampshire village (UK), Michael Mayerfield Bell documented perceptions that 'moneyed residents' used front doors and 'ordinary people' back doors. ${ }^{48}$ Past practices of back doors evaded formality and, at times, the law. Carolyn Downs observes,

${ }^{48}$ Michael Mayerfield Bell, Childerley: Nature and Morality in a Country Village, (Chicago: Chicago University Press, 1994), p. 51. 
One elderly blind woman in Lancaster earned a good living as a bookmaker.

She used to leave her back door open, and bets were placed on the shelf by the door, a slip of paper wrapped round the stake $[\ldots]^{49}$

Standing outside the back door (see image two), Miller and Whalley reflected on this house, houses in which they had lived previously, and the importance of class identity in choosing to use the back, rather than front door. The back door became a place to reflect on the relation between a house and community. It was clear their engagement with the door was powerfully felt and, as they talked, Whalley rested against the closed door. The door offered security, not because it was closed, but because of a promise of openness. For Miller and Whalley, interior and exterior worlds blur at a back door, rather than meeting at a neat intersection. In their conversation and action, the exterior of the door was intimately connected to the world inside the house, an effect heightened by the staged series of doors to the house. Standing in the courtyard, we were implicated in a world of permissive rather than fixed entrances that led, eventually, into the house itself.

We tried the front door. Miller and Whalley opened the door, invited us in and stepped back, awkwardly, to let us into the hall. I recall my own visits, knocking and watching through the back door window, being waved through by Miller, midst cooking, or Whalley at the table. Testing the front door brought more mannered, co-present practices of welcome, through which outside and inside were sharply delineated. Access

${ }^{49}$ Carolyn Downs, 'Working Class Gambling Entrepreneurs', in Work and Society: Places, Spaces and Identities, ed. by Paul Taylor and Paul Wagg (Chester: University of Chester Press, 2014), pp. 95-120 (p. 112). 
involved a process of those inside going to the door, opening up the interior, enabling others to enter. The process felt stilted, transactional. It echoed the uneasy, impersonal entrance at the front door in Olde Wolbers' work and Busch's broader observation that '[m]ost car-dependent Americans know that their front door is rarely opened and entered', instead that it contributes symbolically to 'that elusive composition of rooms, objects, and ideas we think of as home.' 50 The effect of using the door was a palpable, resounding sense of unease, as if Miller and Whalley had let us into a house that was not their own.

It appeared that Miller and Whalley were more comfortable with welcome at a distance, in which visitor/guest and resident/host meet well away from a threshold: waved in at windows, rather than let in at doors. Where back doors constitute permissive thresholds, the act of opening is done from outside, and meetings take place within a room, rather than at a threshold. This said, opening this particular back door often draws the attention of Miller and Whalley's two Dalmatians, William and Stephen, who whirl around, inside and out, further unsettling any formality of welcome. By practising a back door, visitors are able to find their way for a time, retaining a connection with their own world as they cross into that of others.

During discussions, Miller and Whalley explained that, at times, they have been aware of people outside the doors. One afternoon, Miller found a man standing, crying, in the courtyard, looking at the house. The last time the man had stood there, his

\footnotetext{
${ }^{50}$ Busch, The Geography of Home, p. 33.
} 
grandmother had died and was being carried through the back door. ${ }^{\mathbf{5 1}}$ Miller asked him in, aware theirs is an old house, which had been inhabited by and important to others before them. It was, Miller explained, as if this history transcended conventional limits of house ownership, framing ownership in terms of sensitively managing limits. While Miller and Whalley were aware of their own histories of doors, they had also become aware of past practices in this house, their own emerging practices there, and of navigating new events in the light of this emerging knowledge. They were, themselves, on a spiral of 'becoming resident', becoming increasingly familiar with ways of practising this house as home.

Both the laboratory and Olde Wolbers' installation indicate that a front door can impose and regulate relations between people in ways that may be difficult to escape once inside. Conversely, the laboratory suggests that back doors allow for more extended negotiation of crossing, with less formal framing and where performances of entrance are less tied to specific acts of welcome at thresholds. While there is more analysis to be done with doors in arts practice, these works demonstrate there is value in attending closely to particular doors, especially those in domestic dwellings. Future work might look further at whether acts at front doors offer productive points of connection between home and neighbourhood. By attending more closely to how artists articulate and reimagine practices of doors between places, researchers might offer critical perspectives

\footnotetext{
${ }^{51}$ There is established literature on whether the door is an appropriate threshold for the deceased. Effie Bendann noted, in 1930, that '[t]he custom of carrying out the corpse by some other way than that of the ordinary door is very common', in Death Customs: An Analytical Study of Burial Rites (Abingdon: Routledge, 2010), p. 57.
} 
on the design of doors to and within homes. Certainly, the projects here revealed that attending to the particularities of practising doors allows artists to address a place, from within and without, and began to reveal the ways in which people situate themselves, and are situated by others, in or between places.

\section{Internal Doors}

Whalley explained that theirs is a house of 'extraordinary doors' and that few work as you might expect. ${ }^{52}$ Miller and Whalley walked us through the house, opening doors, explaining idiosyncrasies and the cupboards and rooms onto which doors opened: a meat-cupboard that closes with a heavy iron bar, the sitting room door that opens with a will of its own, and the door to the attic, barely four foot high. In so doing, they revealed the life they live in the house. There was a playful precariousness to each door, which they were reluctant to 'fix'. Miller and Whalley live in dialogue with doors, in ways enhanced and enlivened, rather than troubled, by a door slipping its catch. Acts of opening and closing doors contribute to a closely held set of practices by which we make ourselves at home. As Bachelard reflects,

If one were to give an account of all the doors one has closed and opened, of all the doors one would like to re-open, one would have to tell the story of one's entire life. ${ }^{53}$

52 Miller, et. al, Between 13 and 15 Steps.

${ }^{53}$ Bachelard, The Poetics of Space, p. 224. In response, McAuley questions whether it may be possible to 'recount the history of Western theatre by telling the story of the doors that link the on to the off' (McAuley, Space in Performance, p. 87). 
In taking us through their house, Miller and Whalley told a story of their life within, showing, sharing and discovering. It became acutely apparent that doors do not just constitute individual architectural elements, but that they operate in combination, as critical elements of a place and our nuanced experience of that place. Miller and Whalley reflected that the doors add a 'grammar' to their patterns and movements in the house. ${ }^{54}$ In inviting us to become resident, they encouraged us to become familiar with the detail of this grammar, certainly with the downstairs doors. We learned the tactility, weight and duplicitous workings of these doors. Again and again, we practised closing fast the sitting room door, to craft Miller and Whalley's enclosing of the room on cold January evenings. Beyond learning this grammar, the laboratory became an opportunity to enter into a dialogic practice with Miller and Whalley, contributing to daily practices of individual doors and carefully, cautiously, but inevitably, life within their home. The effects of this work continue. A couple of years later, Whalley found the laboratory remained a powerful influence on her sense of doors in the house.

\section{The Larder Cupboard Door}

On the first evening, Miller and Whalley proposed we look through the kitchen cupboards, add something we felt was missing and cook dinner from their ingredients and ours, to become familiar with using the doors and the interior and exterior they defined. We were drawn to the larder, a cupboard brimming with flours, cereals and spices, its

\footnotetext{
${ }^{54}$ Miller, et. al, Between 13 and 15 Steps.
} 
old, panelled door over-painted in cream. Cupboards offer the means for practices and possibilities. In adding to cupboards, we altered these possibilities in ways Miller and Whalley would discover in subsequent spirals of the work. It became clear that doors intervene in a place, interrupting the flow within a room, in this case through opening or closing doors, leaving them open or ajar, or reaching into a place that was both here and beyond. As we sat down to eat, we closed the doors around us, remaking a single place, in which we sat together.

Unlike other doors in this article, the larder and these kitchen cupboard doors were premised on reaching in and out, rather than passing through. While John Horton and Peter Kraftl consider cupboard doors in their exploration of 'clearing out a cupboard', this experiment suggests that cupboards require further investigation, as places that are within yet separate to, and which transform a place. ${ }^{55}$ This extends Kohane and Hill's sense of movement at doors as 'circulation'. At open cupboard doors, we remain in one place and stretch beyond it, finding other worlds through sight and touch. Yet, these worlds beyond doors are limited and of a different order to Arnold Aronson's sense of the door as 'a sign of the liminal, the unknown, the potential, the terrifying, the endless' ${ }^{\mathbf{5 6}}$ While doors bring a fascination for the world beyond, so they also allow us to attend to the re-crafting of worlds that are quite ordinary and familiar.

\footnotetext{
55 John Horton and Peter Kraftl, 'Clearing out a Cupboard: Memory, Materiality and Transitions', in Owain Jones and Joanne Garde-Hansen, Geography and Memory: Explorations in Identity, Place and Becoming (Basingstoke: Palgrave Macmillan, 2012) pp. 25-45.

${ }^{56}$ Arnold Aronson, 'Their Exits and Their Entrances: Getting a Handle on Doors', New Theatre Quarterly 20.4 (November 2004), pp. 331-340 (p. 340).
} 


\section{[Insert Image 3]}

\section{The Passageway Door}

There are two doors to the passageway, one to the street, the other to the courtyard. Miller and Whalley led a discussion just inside the door from the street (see image three), and, later, we opened and closed doors along the passageway, testing ourselves to find each door in the dark. One evening, Miller and Whalley invited us to sit in the passageway, which they had set out with seats, blankets, a rug, a picture on the wall and a film of a fire in a grate. We sat, listening to the talk and laughter of passers-by and the thrum of passing cars. After recent rain and, so close to the street, sounds were sharp, more so as the door to the street did not quite fit the frame. At any moment, someone might have pushed open a door at either end.

Von Meiss describes '[T]he soft, progressive, threshold of some of Frank Lloyd Wright's houses', which allows gradual entrance to each house. ${ }^{57}$ The door between street and passageway constituted such a threshold. Yet, this was also a relatively unclear threshold. Miller will often have to ask people on the street to move out of the way, as if the door comprises an indiscernible breach in the limit and practices of the street, a threshold beyond the limits of perception. The door itself is loosely determined. It might, in fact, be a gate, although the small brass door handle suggests an internal, even a cupboard door, and the door fits within the range of doors to houses, shops and

\footnotetext{
${ }^{57}$ Von Meiss, Elements of Architecture, p. 219, emphasis in original.
} 
passageways on the street. The soft, progressive threshold continues in highly sensory ways: the cooler, quieter, darker passageway is an entirely different environment from the street. Miller describes the passageway as a 'semi-domestic decompression chamber', in which he feels the 'powerful' effect of 'the weight of air between doors. ${ }^{58}$ For Whalley, when the street is quiet, the passageway becomes an anechoic chamber, in which one hears only one's heartbeat. ${ }^{59}$ They will, independently, often wait a while before opening the far door (see image four). Miller will lean back and rest against the door, trusting no one will follow; occasionally, Whalley will dance.

\section{[Insert Image 4]}

Despite their life and work together, and their experience in this very particular house, neither Miller nor Whalley had spoken about how they experience and practise this door, yet they each identified it as critical to their daily life, their sense of the world and their home. It is not that experiences and practices of place must be shared; in part they are significant as personal moments of reflection and reorientation. However, such acts reveal closely worked understandings of place, which, without attention, we run the risk of missing and under-valuing, if not losing entirely.

\section{Closure}

${ }^{58}$ Miller, et. al, Between 13 and 15 Steps.

${ }^{59} \mathrm{An}$ anechoic chamber is designed to absorb sound entirely and so eliminate echo. 
In these case studies, both Olde Wolbers and Miller and Whalley demonstrated that, extending Von Meiss's theory, doors are critical places, objects and thresholds that we experience through practice. The more we understand about how artists practise doors, the more we can begin to chart how they articulate interconnecting places, and contribute to, intervene in and re-imagine these places of intersection and the places beyond. By attending to individual artworks, we can trace how artists understand and practise a door as a critical element in their engagement with place. The work by Olde Wolbers and by Miller and Whalley enables us to actively reflect on the ways in which we practise doors in everyday life. It asks that we attend to the effects and implications of past and present practices of particular doors, and address the intersection of places, in this case within a home and between a home and its surroundings.

As the projects here demonstrate, artists practise and reflect on doors in very different ways. While, in Yes, These Eyes are the Windows, Olde Wolbers opened up a house by revealing and commenting on material forms, Miller and Whalley created opportunities for practical encounter and conversation. In our broader study of the door, Wagner and I seek to identify and investigate a diverse set of artistic practices of doors, which, together, speak to the practicalities, implications and possibilities of practising doors in artistic engagement with a place. Our sense is that this work demonstrates the potential for further exploration of points of crossing and connection in the practice and study of artistic engagement with place. 
As artists reveal detail of place and crossings at doors, so doors may, in turn, impact on an artist's practice. For Stewart Brand, a 'house and its occupants mold to each other twenty-four hours a day, and the building accumulates the record of that intimacy' ${ }^{60}$ In Olde Wolbers' installation, there was no such daily moulding in the house as a home. Instead, the work invited spectators to consider past mouldings in a house, at a point of impending remodelling. Miller and Whalley confessed to feeling uncomfortable creating fictions in their home, perhaps because fictionalising familiar practices might place at risk a precious, closely held, and lived accumulation and 'record' of intimacy. As performance-makers who have often reflected playfully on their life and work together, they found, to their surprise, that working at home asked for a different approach. Beyond their own lives, Miller and Whalley were acutely aware of past inhabitants' sense of the house and of the dwellings and the lives of those close by. In each project, it appeared that the ways in which artists work with a door are conditional on their particular personal connection with a place and the ways in which a building is practised (or not), in this case as a home.

By attending to the ways in which artists practise doors, we contribute to an emerging conversation between performance and architecture: on acts in dialogue with forms and structures, in this case at the door. By going further, and addressing other elements of architecture in performance and in everyday life, we might better understand our experiences of practising place and, thereby, the worlds in and between which we

\footnotetext{
${ }^{60}$ Stewart Brand, How Buildings Learn: What happens after they're built (New York: Penguin Books, 1995), p. 7.
} 
find ourselves. By investigating how artists practise elements of architecture, we can open up significant new conversations on performances of place, by identifying, evidencing and reflecting on the significance of interactions with familiar forms, hidden in plain sight, which are critical to processes of attending to, experiencing and articulating intersecting places, and determining our relationship to people and place. In so doing, it is vital we recognise the breadth of experiences of specific elements, from the ordinary to the extraordinary. As the projects here demonstrated of the door, ordinary acts prove particularly compelling if not, in their own ways, extraordinary. By performing such acts, by opening up and closing fast, by pushing away and pulling to, by waiting at, squeezing between or passing through, we enter into a complex and close engagement with place and the ways in which we pass from the place we are in to that which lies ahead. 